\title{
Interleukin-6 displays lung anti- inflammatory properties and exerts protective hemodynamic effects in a double-hit murine acute lung injury
}

Guillaume Voiriot ${ }^{1,2^{*}}$, Keyvan Razazi ${ }^{1,2,3}$, Valérie Amsellem¹, Jeanne Tran Van Nhieu ${ }^{2,4}$, Shariq Abid ${ }^{1}$, Serge Adnot ${ }^{1,2,5}$, Armand Mekontso Dessap ${ }^{1,2,3+}$ and Bernard Maitre $1,2,3+$

\begin{abstract}
Background: Interleukin 6 (IL-6) is a predictive factor of poor prognosis in patients with acute respiratory distress syndrome (ARDS). However, its acute pulmonary hemodynamic effects and role in lung injury have not been investigated in a clinically relevant murine model of ARDS.

Methods: We used adult C57BI6 wild-type (WT) and IL-6 knock-out (IL-6KO) mice. The animals received intravenous recombinant human IL-6 (rHulL-6) or vehicle followed by intratracheal lipopolysaccharide (LPS) or saline before undergoing low tidal volume mechanical ventilation (MV) for $5 \mathrm{~h}$. Before sacrifice, right ventricular systolic pressure and cardiac output were measured and total pulmonary resistance was calculated. After sacrifice, lung inflammation, edema and injury were assessed with bronchoalveolar lavage (BAL) and histology. In other experiments, right ventricular systolic pressure was recorded during hypoxic challenges in uninjured WT mice pretreated with rHulL-6 or rHulL-6 + non-selective nitric oxide synthase inhibitor L-NAME or vehicle.

Results: IL-6KO(LPS+MY) mice showed a faster deterioration of lung elastic properties and more severe bronchoalveolar

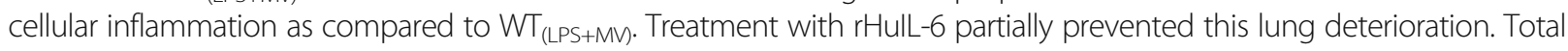
pulmonary resistance was higher in $\mathrm{IL}_{-6 \mathrm{KO}}(\mathrm{LPS}+\mathrm{MV})$ mice and this increase was abolished in rHulL-6-treated IL-6KO mice. Finally, rHulL-6 reduced hypoxic pulmonary vasoconstriction in uninjured WT mice, an effect that was abolished by co-treatment with L-NAME.

Conclusions: In a double-hit murine model of ARDS, IL-6 deficient mice experienced more severe bronchoalveolar cellular inflammation as compared to wild-type littermates. Furthermore, lL-6 deficiency caused marked acute pulmonary hypertension, which may be, at least partially, due to vasoactive mechanisms. A dysregulation of nitric oxide synthase may account for this observation, a hypothesis that will need to be investigated in future studies.
\end{abstract}

Keywords: Interleukin-6, Acute lung injury, Acute respiratory distress syndrome, Mechanical ventilation, Pulmonary hypertension, Nitric oxide synthase

\footnotetext{
* Correspondence: guillaume.voiriot@aphp.fr

${ }^{\dagger}$ Equal contributors

${ }^{1}$ INSERM, Unité U955 (Institut Mondor de Recherche Biomédicale), Créteil,

France

${ }^{2}$ Faculté de Médecine, Groupe de recherche clinique CARMAS, Université

Paris Est, Créteil, France

Full list of author information is available at the end of the article
}

\section{) Biomed Central}

(c) The Author(s). 2017 Open Access This article is distributed under the terms of the Creative Commons Attribution 4.0 International License (http://creativecommons.org/licenses/by/4.0/), which permits unrestricted use, distribution, and reproduction in any medium, provided you give appropriate credit to the original author(s) and the source, provide a link to the Creative Commons license, and indicate if changes were made. The Creative Commons Public Domain Dedication waiver (http://creativecommons.org/publicdomain/zero/1.0/) applies to the data made available in this article, unless otherwise stated. 


\section{Background}

Acute Respiratory Distress Syndrome (ARDS) is a lifethreatening syndrome consisting of acute onset respiratory failure caused by noncardiogenic edema and characterized by hypoxemia and radiological bilateral lung infiltrates [1]. The pathology includes alveolocapillary membrane abnormalities due to various agents either inhaled or delivered to the lungs via the blood circulation [2]. The pathogenesis involves a potent inflammatory response, involving a complex group of mediators including interleukin-6 (IL-6). This pleiotropic cytokine is produced at sites of tissue inflammation and released into the circulation by a variety of different cell types, including macrophages, lymphocytes, endothelial cells, epithelial cells and fibroblasts [3] during sepsis and acute organ injuries. IL-6 acts as a major proinflammatory mediator for the induction of the acute phase response [4], leading to a wide range of local and systemic changes including fever, leucocytes recruitment and activation, hepatic regeneration and hemodynamic effects. Considering the key role of IL- 6 in mediating the acute phase response, its value as a prognostic biomarker in sepsis and various acute organ injuries has been extensively investigated in clinical and experimental studies. Plasma and/or broncho-alveolar levels of IL-6 have been identified as early biomarkers of lung injury [5-8] and predictive factors of prolonged mechanical ventilation, organ dysfunctions, morbidity and mortality in ARDS [9-12]. However, whether the increased plasma or tissue levels of IL-6 observed in sepsis and ALI/ARDS, contribute to organ injury, prevent it or merely describe it, remains controversial [13]. Indeed, beneficial anti-inflammatory effects of IL-6 have been shown in experimental lung injury [14-16]. This hypothesis has not been tested in a lung injury model closely relevant to the clinical situation. Furthermore, the pulmonary hemodynamic effects of IL-6 in ARDS remain unclear, even though pulmonary vascular dysfunction is a major hallmark of ARDS [17]. In this study, we used a double-hit, clinically relevant murine model of ARDS combining lipopolysaccharide (LPS) aspiration followed by 5-h low tidal volume mechanical ventilation. We applied this model to IL-6 gene knock-out mice to assess the effects of IL-6 during ARDS on respiratory mechanics, lung inflammation, and right-sided ventricular hemodynamics.

\section{Methods}

\section{Animals}

Mice lacking IL-6 (IL-6 ${ }^{-/-}$) were generated by homologous recombination on the $\mathrm{C} 57 \mathrm{Bl} / 6$ and $\mathrm{IL}-6^{-/-}$genetic background [18]. The wild-type IL- $6^{+/+}$mice (WT mice) and mutant homozygous knock-out IL- $6^{-/-}$mice (IL-6KO mice) were adult male littermates obtained by breeding heterozygous mutants. All animal care and procedures were performed after approval of the Institutional Animal Care Committee, in accordance with official guidelines of the French Ministry of Agriculture for the experimental use of animals.

\section{Animal protocol}

Mice were anesthetized with inhaled 5\% isoflurane (Abbott, Rungis France) and were maintained spontaneously breathing. They received retro-orbital intravenous injections [19] of either $3 \mu \mathrm{g} / \mathrm{kg}$ of recombinant human IL-6 (rHuIL-6, PromoCell, Heidelberg, Germany) or vehicle (saline). Following the injection, $2 \mu \mathrm{l} / \mathrm{g}$ of body weight volume instillate consisting of $2 \mu \mathrm{g} / \mu \mathrm{l}$ of Escherichia coli 055:B5-derived LPS (Sigma-Aldrich Chimie, Lyon, France) or vehicle (saline) was administered into the distal part of the oropharynx and aspirated into the lower respiratory tract. The selection of rHuIL-6 doses was based on previously published studies with intravenous rHuIL-6 in mouse models of sepsis [20] and acute myocardial infarction [21]. Following recovery from anesthesia, the mice were returned to their cage with free access to water and food.

Eighteen hours later, mice were anesthetized with a combination of intraperitoneal pentobarbital $(30 \mu \mathrm{g} / \mathrm{g}$ of body weight, Hospira, Meudon La Forêt, France) and inhaled 5\% isoflurane (Abbott, Rungis France). Following a second intravenous injection of $\mathrm{rHu}$ IL-6 (identical to the first injection) or vehicle, the larynx was surgically exposed and the trachea intubated orally under direct vision with a metal cannula (internal diameter of $1 \mathrm{~mm}$, Harvard Apparatus, Les Ulis, France). The tracheal cannula was properly secured with surgical thread (Ethicon 3-0, Ethicon, Auneau, France) before being connected to a mechanical ventilator. The cervicotomy was closed with surgical thread (Ethicon 6.0, Ethicon, Auneau, France).

\section{Mechanical ventilation}

The ventilator regimen has been extensively detailed elsewhere [22]. Briefly, mice were ventilated in the supine position using humidified gas $(20 \mathrm{mgH} 2 \mathrm{O} / \mathrm{L}$ absolute humidity, MR410 humidifier, Fischer \& Paykel Healthcare, Courtaboeuf, France), with a tidal volume of $8 \mathrm{~mL} / \mathrm{kg}$ of body weight, a respiratory rate of $180 / \mathrm{min}, 3$ $\mathrm{cmH} 2 \mathrm{O}$ end-expiratory pressure, and $\mathrm{FiO} 2$ of 0.5 , by means of a computer-driven small-animal ventilator (flexiVent, Scireq, Montreal, Canada). Mechanical ventilation lasted $5 \mathrm{~h}$ with continuous anesthesia maintained by $1.5 \%$ isoflurane and muscle paralysis using intraperitoneal pancuronium given at the onset of mechanical ventilation and then every two hours $(0.8 \mu \mathrm{g} / \mathrm{g}$ of body weight, Organon, Puteaux, France) to ensure passive mechanical conditions. Mice received intraperitoneal warm fluid boluses (5\% dextrose with $9 \mathrm{~g} / \mathrm{L} \mathrm{NaCl}$ ) at the onset $(20 \mu \mathrm{L} / \mathrm{g}$ of body weight) and every hour $(10 \mu \mathrm{L} / \mathrm{g}$ of body weight) during mechanical ventilation. 


\section{Experimental design}

The experimental design included six groups: $\mathrm{WT}_{(\mathrm{MV})}$ (WT receiving saline instillation and vehicle injections and undergoing mechanical ventilation $(\mathrm{MV})), \mathrm{WT}_{\text {(LPS }}$ + MV) (WT mice receiving LPS instillation and vehicle injections and undergoing mechanical ventilation), WT + rHuIL-6 $6_{(\mathrm{LPS}+\mathrm{MV})}$ (WT mice receiving LPS instillation and rHuIL-6 injections and undergoing mechanical ventilation), IL-6KO $\mathrm{KMV}_{(\mathrm{V})}$ (IL-6KO mice receiving saline instillation and vehicle injections and undergoing mechanical ventilation), IL-6KO $\mathrm{CLPS}_{(\mathrm{MV})}$ (IL-6KO mice receiving LPS instillation and vehicle injections and undergoing mechanical ventilation) and IL-6KO + rHuIL-6 $6_{(\mathrm{LPS}+\mathrm{MV})}$ (IL-6KO mice receiving LPS instillation and rHuIL-6 injections undergoing mechanical ventilation (MV).

\section{Model assessment}

To contrast the effects of the double-hit challenge (LPS + mechanical ventilation) with those of either LPS administration alone, we subjected wild-type C57BL6 adult male mice to LPS or vehicle (saline) aspiration without mechanical ventilation. We then assessed lung injury and measured total cell count, and total protein, IL-6, TNF $\alpha$ and MIP-2 concentrations in BAL fluid as described below.

\section{Respiratory mechanics}

Special features of the flexiVent ventilator include a continuous monitoring of airway pressures and a precision computer-controlled piston capable of accurately measuring the delivered volume (with appropriate corrections for gas compression) and producing any desired waveform, allowing respiratory mechanics assessment with the forced oscillation technique (FOT) and pressure-volume curves [22]. Following a stabilization period of $5 \mathrm{~min}$, mice were inflated twice to a transrespiratory pressure of $30 \mathrm{cmH}_{2} \mathrm{O}$ to establish a standard volume history. Peak inspiratory pressure was measured at initiation of mechanical ventilation, before and after volume history standardization, and then hourly. Respiratory system dynamic compliance and elastance were measured using the single frequency FOT at initiation of mechanical ventilation, before and after volume history standardization, and then hourly to capture the time course and detailed response to mechanical ventilation. The respiratory system quasi-static compliance was measured using a pressuredriven pressure-volume curve at start (before and after volume history standardization) and end of mechanical ventilation. Before the end of the timed ventilator proto$\mathrm{col}$, mice underwent hemodynamic measurements [22].

\section{Hemodynamic measurements}

Both the right jugular vein and left carotid artery were isolated through the cervical midline incision using a stereomicroscope (Leica MZ 7.5, Leica Microsystems, Nanterre, France). An ultra-miniature $0.47 \mathrm{~mm}$ high fidelity pressure transducer catheter (SPR-671, Millar Instruments, Houston, TX) was inserted into the right jugular vein and advanced into the right ventricle. The micromanometer was calibrated in vitro, firstly electronically and secondly against a column of mercury with the reference zero level taken at mid chest. Right ventricular systolic pressure was measured during a short end-expiratory ventilatory pause using a Gould transducer (Gould, Cleveland, USA) and a Notocord system (Emka Technologies, Paris, France). Cardiac output was measured with the transpulmonary thermodilution technique [23]. Briefly, a $0.34 \mathrm{~mm}$ external diameter thermistor microprobe (Columbus Instruments, Columbus, $\mathrm{OH}$ ) was inserted into the left carotid artery and advanced into the aortic arch, where changes in aortic blood temperature were measured. A $0.5 \mathrm{~mm}$ external diameter catheter placed in the right jugular vein was advanced into the right atrium for bolus injection of $20 \mu \mathrm{L}$ of $\mathrm{NaCl} 9 \mathrm{~g} / \mathrm{L}$ solution at $20^{\circ} \mathrm{C}$. Five consecutive cardiac output measurements were obtained using the Cardiomax-III system (Columbus Instruments) and total pulmonary resistance was calculated as the ratio of right ventricular systolic pressure to cardiac output.

\section{Specimen collection}

At the end of the timed ventilation protocol and after completion of hemodynamic measurements, mice were exsanguinated via sectioning of the left carotid artery. Arterial blood gases were determined in five $\mathrm{WT}_{(\mathrm{LPS}+\mathrm{MV})}$ group mice. Bronchoalveolar lavage (BAL) was performed with four separate $0.5 \mathrm{~mL}$ aliquots of saline at $20^{\circ} \mathrm{C}$ followed by lung fixation (paraformaldehyde $4 \%$, inflation pressure 25 $\mathrm{cmH}_{2} \mathrm{O}$ for $1 \mathrm{~min}$ ) and paraffin embedding. The total cell count of BAL fluid was determined from a fresh BAL fluid specimen using a Malassez hemocytometer. The BAL fluid was centrifuged $\left(1600 \mathrm{rpm}, 7 \mathrm{~min}\right.$ at $\left.4^{\circ} \mathrm{C}\right)$, the cell pellet was diluted in saline, and differential cell counts were done in four $\mathrm{WT}_{(\mathrm{LPS}+\mathrm{MV})}$ mice and four IL-6KO $\mathrm{K}_{(\mathrm{LPS}+\mathrm{MV})}$ mice on cytocentrifuge preparations (Cytospin 3; Shandon Scientific, Cheshire, UK) stained with Diff-Quick (Baxter Diagnostics, McGaw Park, IL). Cell-free supernatants were stored at $-80^{\circ} \mathrm{C}$ for subsequent duplicate measurements of total protein (Bio-Rad Protein Assay) and cytokine concentrations [macrophage inflammatory protein 2 (MIP-2), tumor necrosis factor $\alpha$ (TNF- $\alpha$ ) and IL- 6 using an ELISA immunoassay kit, (R\&D systems, Abingdon, UK) performed in accordance with manufacturer's instructions.

\section{Histological analysis}

Paraffin lungs blocks were sectioned at $5 \mu \mathrm{m}$ thickness and mounted on glass slides. After staining with hematoxylin and eosin, all slides were examined under a light microscope by an experienced pathologist in a blinded fashion. 
Lung injury was assessed using a histological scoring system designed to evaluate the heterogeneous lesions of lung injury and adapted from previously published scores $[24,25]$. Three pathological processes (edema, congestion/ hemorrhage and leukocyte infiltration) were scored in the two main non-alveolar structures of the lung (veins and bronchi/arteries) using the two following scales: 1) an intensity scale ( 0 to $4: 0$ if absent, 1 if mild, 2 if moderate, 3 if severe, and 4 if very severe), and 2 ) an extension scale (0 if absent, 1 if $<25 \%$ of lung involvement, 2 if $25-50 \%$ of lung involvement, 3 if $50-75 \%$ of lung involvement, and 4 if $>75 \%$ of lung involvement). Three pathological processes (thickness of the alveolar wall, neutrophil recruitment in airspace, and macrophage aggregation in airspaces) were scored in the alveoli using the same scales as above. A composite score of intensity and extension (intensity score times extension score) was calculated for each pathological process in each structure. The resulting values (0 to 16) were added to yield partial scores of edema in veins and bronchi/arteries ( 0 to 32 ), congestion/hemorrhage in veins and bronchi/arteries ( 0 to 32 ), leukocyte infiltration ( 0 to 48 , associating leukocyte infiltration in veins and bronchi/ arteries and thickness of the alveolar wall) and alveolitis ( 0 to 32 , associating neutrophil aggregation and macrophage aggregation in airspaces). Finally, the four partial scores were added to yield a global lung injury score (0 to 144).

\section{Acute hypoxic challenge}

The effects of IL-6 on pulmonary vascular reactivity were evaluated using acute hypoxic challenge. Briefly, three groups of wild-type adult male C57Bl6 mice were randomly assigned to receive rHuIL-6 + L-NAME $(\mathrm{N} \omega$ nitro-L-arginine methyl ester hydrochloride), rHuIL-6 + vehicle or vehicle + vehicle administered as follows:

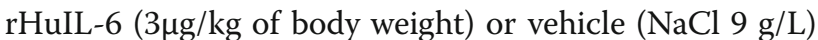
via retro-orbital intravenous injection and L-NAME (50 $\mu \mathrm{g} / \mathrm{g}$ of body weight, Sigma-Aldrich Chimie, Lyon, France) or vehicle $(\mathrm{NaCl} 9 \mathrm{~g} / \mathrm{L})$ intraperitoneally. Five hours later, mice were anesthetized and intubated for mechanical ventilation. A Millar transducer catheter was immediately inserted and advanced into the right ventricle. After thirty minutes of stabilization, the right ventricular systolic pressure was continuously recorded during four consecutive hypoxic challenges ( $\mathrm{FiO} 2$ of 0.08 during $2 \mathrm{~min}$, followed by $5 \mathrm{~min}$ of reoxygenation).

\section{Statistics}

The data were analyzed using the SPSS Base 18.0 statistical software package (SPSS Inc, Chicago, IL). Normality of continuous data was assessed with the Kolmogorov Smirnov test. Because not all data sets were normally distributed we used the median [1st quartile - 3rd quartile] for descriptive statistics unless otherwise stated. Independent samples were compared using the Kruskal-Wallis test followed by a pairwise Mann-Whitney test, with correction for multiple testing by the Benjamini-Hochberg false discovery rate test. Two-tailed $p$ values smaller than 0.05 were considered significant.

\section{Results}

\section{Animals and procedures}

Mice were 18 [14-22] weeks old and weighted 26 [25-29] g. Each group included 8 to 10 animals. All animals survived the protocol.

\section{Model assessment}

Results are reported in Fig. 1. As compared to mice undergoing mechanical ventilation alone (MV group), mice subjected to both LPS and mechanical ventilation (LPS + MV group) showed higher lung injury score, higher total cell count and higher total protein, IL-6, TNF $\alpha$ and MIP-2 concentrations in BAL fluid. As compared to mice receiving LPS alone (LPS group), mice subjected to both LPS and mechanical ventilation (LPS + MV group) showed a higher total cell count and higher total protein, IL-6, and MIP-2 concentrations in BAL fluid.

\section{Respiratory mechanics}

The ventilator settings allowed a tight control of minute ventilation, and partial arterial $\mathrm{CO}_{2}$ pressure as determined in five animals in the $\mathrm{WT}_{(\mathrm{LPS}+\mathrm{MV})}$ group (39 [33-43] $\mathrm{mmHg}$ ). Results of airway pressure monitoring, forced oscillation techniques and pressure-volume curves are shown in Table 1 and Fig. 2. Baseline respiratory mechanics differed slightly between WT and IL-6KO mice. We found a lower quasi-static compliance in IL-6KO mice as compared to WT mice (101 [97-103] vs. 108 [106-112]; $p<0.001)$ at initiation of mechanical ventilation (after volume history standardization) (Fig. 2b), whereas we noted no differences in other parameters of respiratory mechanics. This phenotypic difference in quasi-static compliance between WT and IL-6KO mice was also observed in mice subjected to LPS aspiration with or without injections of rHuIL-6.

At initiation of mechanical ventilation, LPS aspiration was associated with an alteration of respiratory mechanics (lower quasi-static and dynamic compliances, higher dynamic elastance and peak inspiratory pressure) as compared to saline aspiration in both $\mathrm{WT}\left(\mathrm{WT}_{(\mathrm{LPS}+\mathrm{MV})}\right.$ vs. $\left.\mathrm{WT}_{(\mathrm{MV})}\right)$ and IL-6KO mice $\left(\mathrm{IL}-6 \mathrm{KO}_{(\mathrm{LPS}+\mathrm{MV})} \quad v s\right.$. IL-6KO $\left.\mathrm{KO}_{(\mathrm{MV})}\right)$. These differences were not altered by injections of rHuIL-6. We assessed the relative decrease in the quasi-static compliance during the ventilator protocol as previously described. We found a greater alteration in lung compliance in mice exposed to LPS + MV as compared to mice exposed to mechanical ventilation alone $(-25.9 \%$ 



Fig. 1 Bronchoalveolar lavage data and lung histological analysis in wild-type adult mice subjected to lipopolysaccharide (LPS) aspiration, followed by 5-h low tidal volume mechanical ventilation (MV) and their control groups (four groups: control, MV, LPS and LPS + MV; five comparisons: control vs. MV, control vs. LPS, control vs. LPS + MV, MV vs. LPS + MV, LPS vs. LPS + MV). The lung injury score, total cell count, and total protein, IL-6, TNFa and MIP-2 concentrations in BAL fluid were assessed. The symbols $\S$, $\neq$ and + denote Benjamini-Hochberg corrected $p$ values $<0.05$ of Mann-Whitney pairwise comparisons (after Kruskal Wallis test) between the group so marked and the group that received MV alone, LPS alone and the combination LPS + MV, respectively. Data are presented as box and whiskers plots. $N=8-10$ animals per group

$[-31.7 ;-15.1]$ in $\mathrm{WT}_{(\mathrm{MV})}$ vs. $-37.4 \%[-40.0 ;-35.4]$ in $\mathrm{WT}_{(\mathrm{LPS}+\mathrm{MV})}, \quad p=0,001 ; \quad(-18.7 \%[-29.7 ;-9.8]$ in IL$6 \mathrm{KO}_{(\mathrm{MV})}$ vs. $\left(-33.3 \%[-37.7 ;-28.1]\right.$ in $\mathrm{IL}-6 \mathrm{KO}_{(\mathrm{LPS}+\mathrm{MV})}$, $p=0.011)$, without any difference between $\mathrm{WT}$ and IL-6KO mice.

During mechanical ventilation, dynamic elastance and peak airways pressures increased, whereas dynamic and quasi-static compliances decreased. The progressive deterioration of respiratory mechanics was seen in both IL-6KO and WT mice but was greater in LPS-challenged mice $\left(\mathrm{WT}_{(\mathrm{LPS}+\mathrm{MV})}\right.$ and $\left.\mathrm{IL}-6 \mathrm{KO}_{(\mathrm{LPS}+\mathrm{MV})}\right)$ as compared to saline-treated mice $\left(\mathrm{WT}_{(\mathrm{MV})}\right.$ and IL-6KO$\left.(\mathrm{MV})\right)$. Furthermore, the progressive deterioration of respiratory mechanics was faster in $\mathrm{IL}-6 \mathrm{KO}_{(\mathrm{LPS}+\mathrm{MV})}$ mice as compared to $\mathrm{WT}_{(\mathrm{LPS}+\mathrm{MV})}$ mice, as shown by differences in dynamic elastance at H1 (65 [59-83] vs. 56

Table 1 Respiratory mechanics at start ( $\mathrm{H0})$ and after a 5-h (H5) of low tidal volume mechanical ventilation (MV) following a lipopolysaccharide (LPS) or vehicle (saline) aspiration in wild type (WT) and interleukin-6 knock-out (IL-6KO) mice, receiving either recombinant human interleukin-6 (rHulL-6) or vehicle (saline)

\begin{tabular}{|c|c|c|c|c|c|c|}
\hline & $W T_{(M V)}$ & $W T_{(L P S+M V)}$ & $W T+$ rHulL-6 $\sigma_{(L P S+M V)}$ & $\mathrm{IL}-6 \mathrm{KO}_{(\mathrm{MV})}$ & $\mathrm{IL}-6 \mathrm{KO} \mathrm{O}_{(\mathrm{LPS}+\mathrm{MV})}$ & $\mathrm{IL}-6 \mathrm{KO}+\mathrm{rHulL}-6_{(\mathrm{LPS}+\mathrm{MV})}$ \\
\hline Peak Pr HO post-VHS & $10.5[10.3-11.0]$ & $11.6[11.3-12.0]$ & $12.0[11.6-12.5]$ & $10.7[10.1-10.9]$ & $11.6[11.3-12.4]$ & $12.0[11.4-13.6]$ \\
\hline Peak Pr H5 & $17.7[16.3-18.3]$ & 21.5 [20.5-22.0] & $22.6[22.3-23.5]$ & 17.3 [15.6-18.5] & $21.3[20.0-22.5]$ & $20.9[20.6-22.4]$ \\
\hline Cstat HO pre-VHS & 96 [93-106] & $67[54-73]$ & 65 [58-69] & 92 [82-99] & $51[47-62]$ & 54 [49-62] \\
\hline Cstat HO post-VHS & 108 [106-112] & 80 [65-88] & 78 [70-83] & 101 [97-103] & $60[56-65]$ & $64[57-68]$ \\
\hline Cstat $\mathrm{H} 5$ & $82[75-82]$ & $49[41-54]$ & $43[38-50]$ & 78 [71-92] & $41[38-47]$ & $43[42-50]$ \\
\hline Cdyn HO pre-VHS & $32[30-35]$ & 22 [18-25] & 24 [23-26] & $31[27-35]$ & $23[20-27]$ & 26 [22-28] \\
\hline Cdyn HO post-VHS & 53 [49-57] & $32[30-36]$ & $34[30-36]$ & 53 [49-54] & $32[27-40]$ & 35 [31-37] \\
\hline Cdyn H5 & 21 [19-23] & $13[12-14]$ & $13[11-14]$ & 22 [19-28] & $12[12-14]$ & 15 [13-15] \\
\hline Edyn HO pre-VHS & 31 [29-33] & $45[40-55]$ & $44[39-46]$ & 33 [29-37] & 43 [37-49] & $39[37-46]$ \\
\hline Edyn $\mathrm{HO}$ post-VHS & 19 [18-20] & $32[28-33]$ & 30 [29-33] & 19 [19-21] & $32[25-37]$ & 29 [27-33] \\
\hline Edyn $\mathrm{H} 5$ & $48[45-53]$ & 78 [72-86] & 75 [72-90] & 47 [36-52] & 82 [71-85] & 68 [67-75] \\
\hline
\end{tabular}

Data are presented as median [25th-75th percentile]

Abbreviations: Peak Pr peak inspiratory pressures, Cstat quasi-static compliance of the respiratory system (calculated using a pressure-volume curve), Cdyn dynamic compliance of the respiratory system (calculated using the single frequency forced oscillation technique), Edyn dynamic elastance of the respiratory system (calculated using the single frequency forced oscillation technique). Volume history standardization (VHS) consisted in two inflations to an airway pressure of 30 $\mathrm{cmH} 2 \mathrm{O}$. $\mathrm{N}=8$ to 10 animals per group 

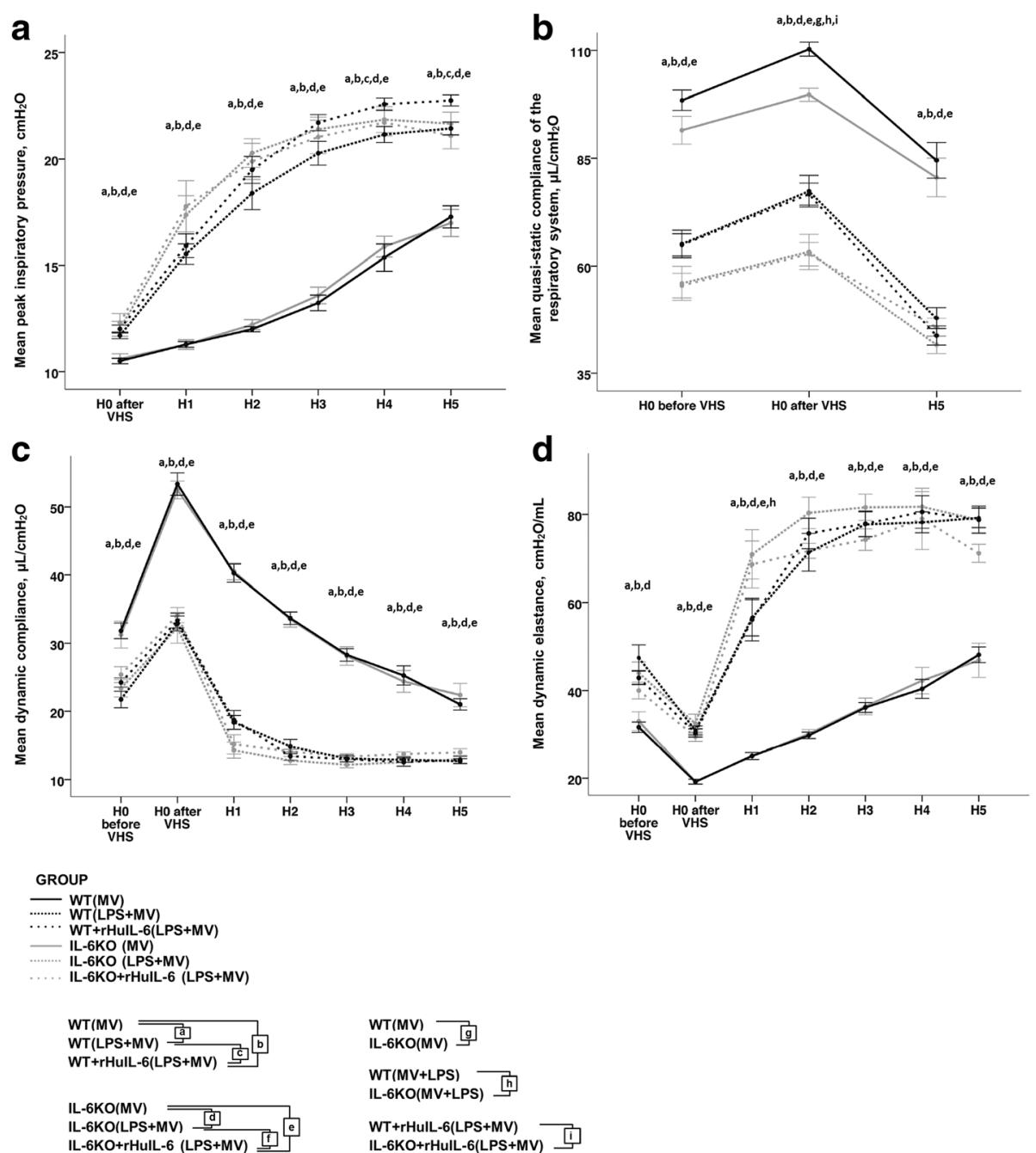

Fig. 2 Respiratory mechanics during 5-h (HO to H5) low tidal volume mechanical ventilation (MV) following either lipopolysaccharide (LPS) or vehicle (saline) aspiration in wild type (WT) and interleukin-6 knock-out (IL-6KO) mice receiving either recombinant human interleukin-6 (rHulL-6) or vehicle (saline). The following respiratory system properties are shown A. Peak inspiratory pressures. B. Quasi-static compliance of the respiratory system calculated using a pressure-volume curve. C. Dynamic compliance of the respiratory system calculated using the single frequency forced oscillation technique. D. Dynamic elastance of the respiratory system calculated using the single frequency forced oscillation technique. Volume history standardization (VHS) consisted in two inflations to an airway pressure of $30 \mathrm{cmH} 2 \mathrm{O}$. The letters a, b, c, d, e, f, g, h and i denote Benjamini-Hochberg corrected $p$ values $<0.05$ of Mann-Whitney pairwise comparisons (following Kruskal Wallis test): WT (MV) Vs. WT (LPS+MV), WT (MV Vs. WT + rHulL-6(LPS+MV),

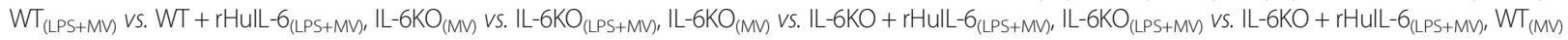


error of the mean. $N=8$ to 10 animals per group

[48-60]; $p=0.016$ ) (Fig. 2d). These differences were not altered by injections of rHuIL-6.

\section{Lung inflammation, edema and injury}

BAL fluid and lung histology data are reported in Figs. 3 and 4, respectively. Lung histology is illustrated in Fig. 5. No differences were observed between $\mathrm{IL}-6 \mathrm{KO}_{(\mathrm{MV})}$ and $\mathrm{WT}_{(\mathrm{MV})}$ mice, except for the IL-6 concentration in BAL fluid.

As compared to their saline-treated controls $\left(\mathrm{WT}_{(\mathrm{MV})}\right.$ and IL-6KO $\left.\mathrm{KMV}_{(\mathrm{M})}\right)$, LPS-challenged mice
$\left(\mathrm{WT}_{(\mathrm{LPS}+\mathrm{MV})}\right.$ and IL-6KO $\left.\mathrm{K}_{(\mathrm{LPS}+\mathrm{MV})}\right)$ showed higher lung inflammation (as assessed by total cell count and MIP2 concentration in BAL fluid, and histological score of alveolitis, Figs. 3a, c and 4C), lung edema (as assessed by total protein concentration in BAL fluid and histological score of lung congestion, Figs. 3e and 4e), and lung injury (as assessed by global lung injury score, Fig. 4a). The differential cell count in $\mathrm{WT}_{(\mathrm{LPS}+\mathrm{MV})}$ mice and IL-6KO $\mathrm{K}_{(\mathrm{LPS}+\mathrm{MV})}$ mice showed a strong predominance of neutrophils in both groups (95\% [94-97,5] and 98\% [93-99], 

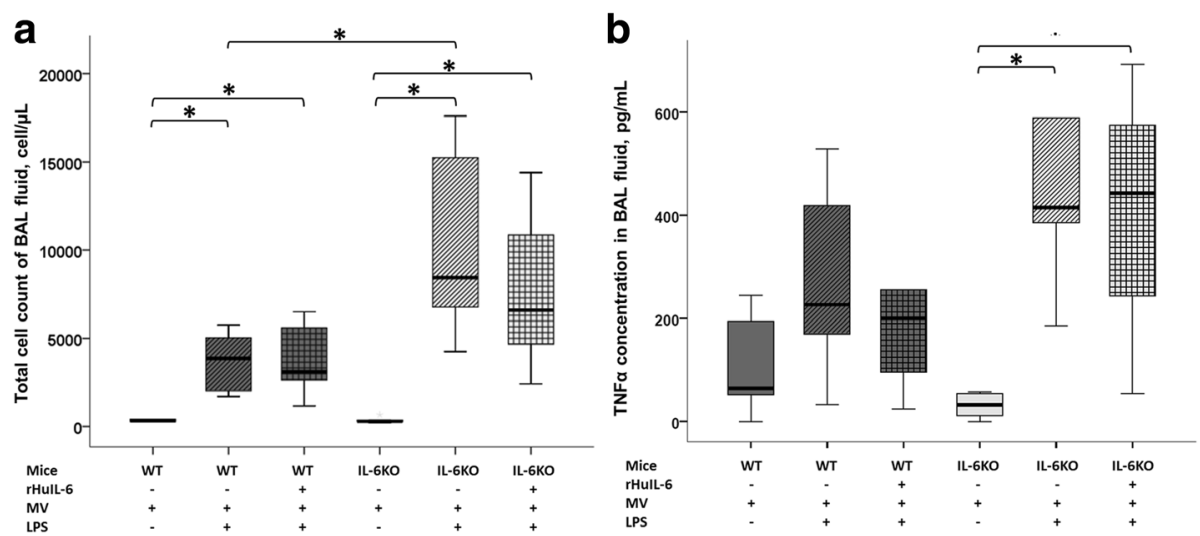

C


Fig. 3 Bronchoalveolar lavage data at the end of a 5-h low tidal volume mechanical ventilation (MV) following either a lipopolysaccharide (LPS) or vehicle (saline) aspiration in wild type (WT) and interleukin-6 knock-out (IL-6KO) mice receiving either recombinant human interleukin-6 (rHulL-6) or vehicle (saline). a Total cell count of BAL fluid (cell/ $\mu \mathrm{L})$. b TNFa concentration in the BAL fluid (pg/mL). c MIP-2 concentration in the BAL fluid $(\mathrm{pg} / \mathrm{mL})$. d IL-6 concentration in the BAL fluid $(\mathrm{pg} / \mathrm{mL})$. e Total protein concentration in the BAL fluid $(\mu \mathrm{g} / \mathrm{mL})$. The symbol * denotes Benjamini-Hochberg corrected $p$ value $<0.05$ of Mann-Whitney pairwise comparisons (following Kruskal Wallis test). Data are presented as box and whiskers plots. $N=6$ to 8 animals per group

respectively; $p=0.28)$. IL-6 was detectable only in all WT groups and in the IL-6KO + rHuIL-6 $(\mathrm{LPS}+\mathrm{MV})$ group (Fig. 3d).

As compared to $\mathrm{WT}_{(\mathrm{LPS}+\mathrm{MV})}$ mice, $\mathrm{IL}-6 \mathrm{KO}_{(\mathrm{LPS}+\mathrm{MV})}$ mice were more prone to lung inflammation and injury, as shown by a higher total cell count in BAL fluid (8440 [5500-16300)] vs. [3860 [1830-5760]; $p=0.008)$ (Fig. 3a) and a trend toward a higher global lung injury score (39 [24-50] vs. 26 [24-35]; $p=0.190)$. As compared to IL-6KO (LPS $+M V)$ mice, IL-6KO + rHuIL-6 (LPS $+M V)$ mice experienced less severe lung injury, as shown by a lower score of alveolitis $\left[\begin{array}{ll}6.0 & {[4.5-6.5]}\end{array}\right]$ vs. 12.0 $[8.0-12.0] ; p=0.007$ ) (Fig. 4c), a lower global lung injury score $(17$ [13-23] vs. 39 [24-50]; $p=0.007)$ 

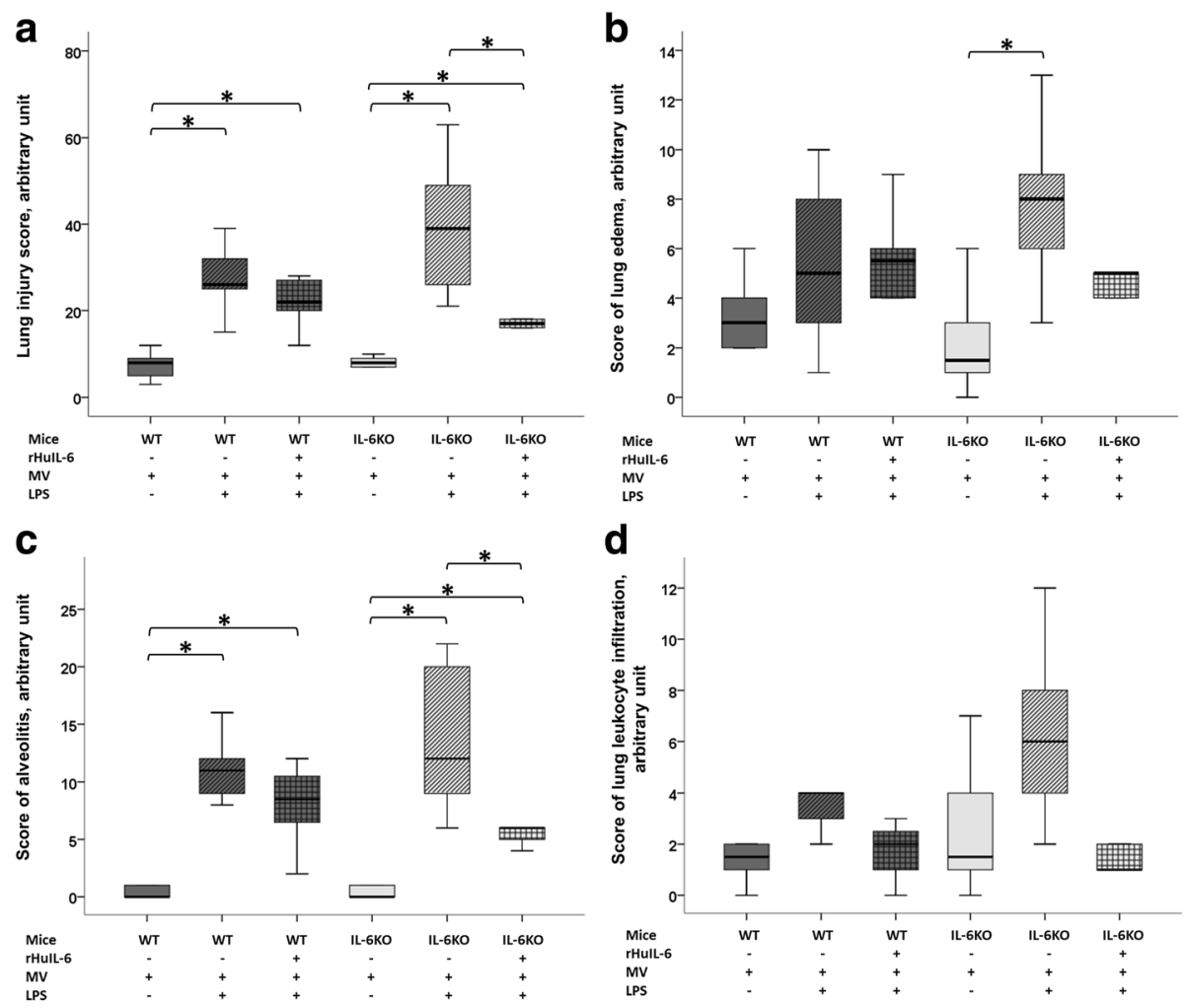

d
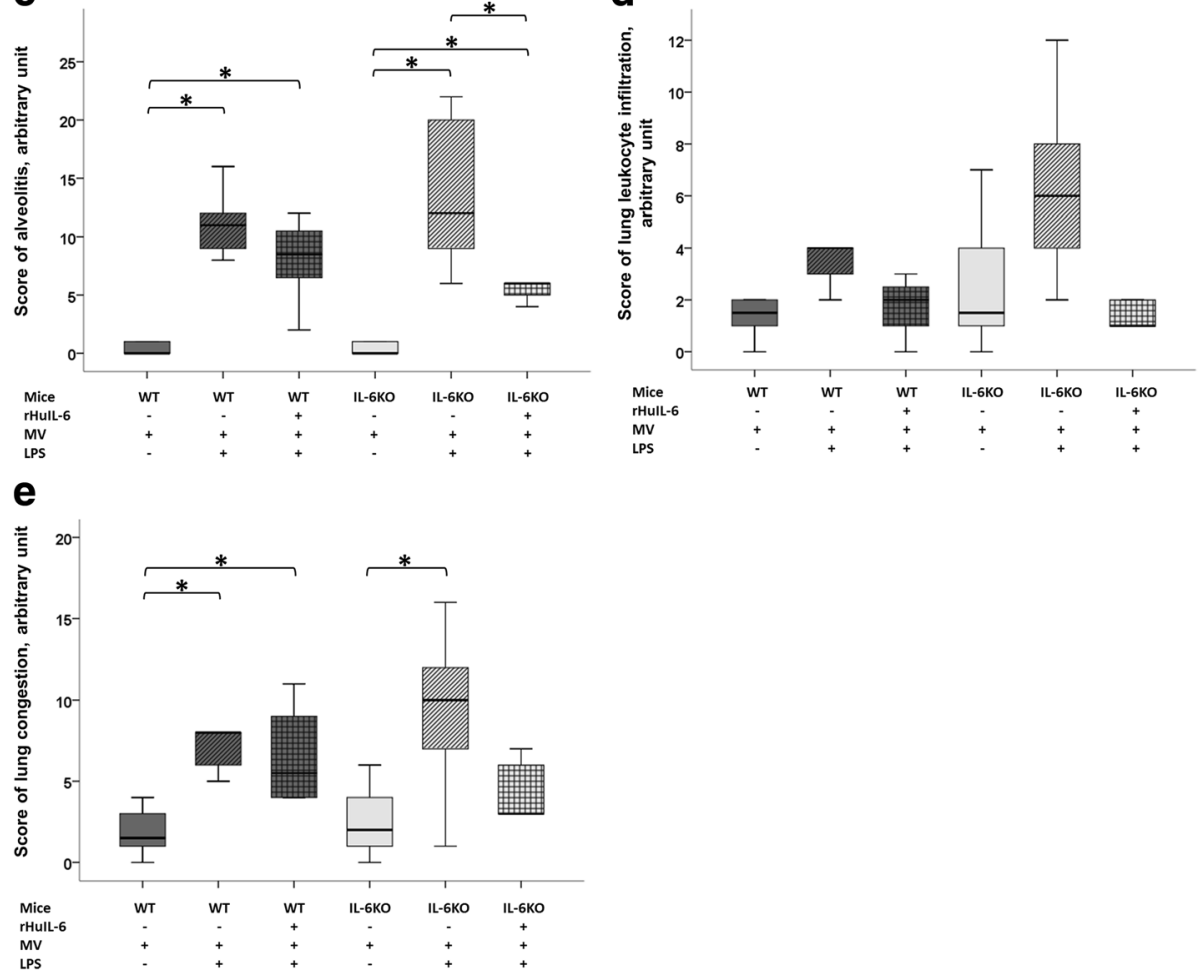

Fig. 4 Lung histological analysis at the end of a 5-h low tidal volume mechanical ventilation (MV) following either a lipopolysaccharide (LPS) or vehicle (saline) aspiration in wild type (WT) and interleukin-6 knock-out (IL-6KO) mice receiving either recombinant human interleukin-6 (rHulL-6) or vehicle (saline). a Global lung injury score. b Lung edema score. c Alveolitis score. d Lung leukocyte infiltration score. e Lung congestion score. The symbol * denotes Benjamini-Hochberg corrected $p$ value $<0.05$ of Mann-Whitney pairwise comparisons (following Kruskal Wallis test). Data are presented as box and whiskers plots. $N=6$ to 8 animals per group

(Fig. 4a) and a trend toward lower total protein concentration (261 [201-574] vs. 455 [311-719]; $p=0.181)$ and lower scores of lung edema $(5.0[3.0-6.5]$ vs. 8.0 [6.0-10.5]; $p=0.129)$, leukocyte infiltration (1.0 [1.0-4.5] vs. $6.0[3.0-10.0] ; p=0.081)$ and congestion (3.0 [3.0-6.5] vs. $10.0[5.0-12.0] ; p=0.083)$.

\section{Hemodynamics}

Hemodynamics results are shown in Fig. 6. As compared to saline-treated controls, LPS-challenged mice showed higher heart rate and right ventricular systolic pressure $\left(\mathrm{WT}_{(\mathrm{LPS}+\mathrm{MV})} v s . \mathrm{WT}_{(\mathrm{MV})}\right.$ and IL-6KO $\mathrm{K}_{(\mathrm{LPS}+\mathrm{MV})} v s$. IL-6K$\left.\mathrm{O}_{(\mathrm{MV})}\right)$. IL-6KO $\mathrm{KO}_{(\mathrm{LPS}+\mathrm{MV})}$ mice had a markedly increased right ventricular systolic pressure (53 [47-60] vs. 37 [33-41]; $p<0.001$ ) (Fig. 6a) and a trend toward a higher total pulmonary resistance $(2.21[1.78-2.41]$ vs. 1.61 [1.37-1.91]; $p=0.09$ ) (Fig. 6b) as compared to $\mathrm{WT}_{\text {(LPS }}$ $+\mathrm{MV})$ mice. These differences were completely abolished in IL-6KO mice treated with rHuIL-6 (IL-6KO + rHuIL-6 $\left.6_{(\mathrm{LPS}+\mathrm{MV})} v s . \mathrm{WT}_{(\mathrm{LPS}+\mathrm{MV})}\right)$. 


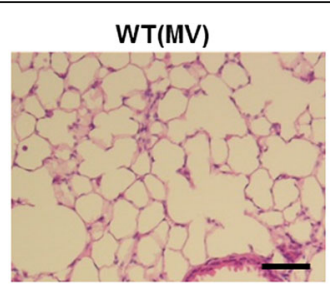

IL-6KO(MV)
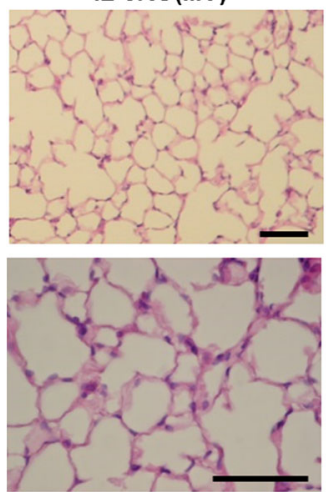

WT(LPS+MV)

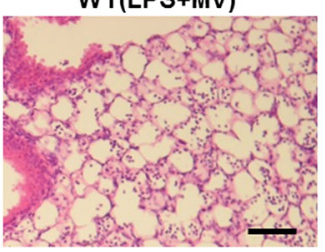

IL-6KO(LPS+MV)
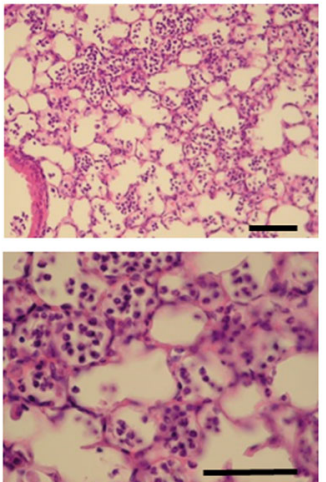

WT+rHulL-6(LPS+MV)



IL-6KO+rHulL-6(LPS+MV)


Fig. 5 Lung histological sections after a 5-h low tidal volume mechanical ventilation (MV) following either a lipopolysaccharide (LPS) aspiration or vehicle (saline) in wild type (WT) and interleukin-6 knock-out (KO) mice receiving either recombinant human interleukin-6 (rHulL-6) or vehicle. Lungs underwent fixation (paraformaldehyde 4\%), paraffin embedding, staining with hematoxylin and eosin, and examination under a light microscope. Magnification $\times 10$ on the two uppers rows of images and X40 on the lower row of pictures. Scale bar: $50 \mu m$. $N=6$ to 8 animals per group

\section{Nitric oxide pathway studies}

To assess whether the acute pulmonary hypertension observed in IL-6KO mice involved the nitric oxide (NO) pathway, we measured right ventricular systolic pressure (RVSP) during four consecutive periods of hypoxia in WT mice previously treated with rHuIL-6, rHuIL-6 + L-NAME or vehicle. Mice treated with rHuIL- 6 showed significantly lower increases in RVSP in response to acute hypoxia as compared to vehicle-treated mice (Fig. 7). The lesser hypoxia-induced pulmonary vasoconstriction was fully prevented by L-NAME administration.

\section{Discussion}

We assessed the right-sided hemodynamic and pulmonary effects of IL-6 deficiency in a septic-like double-hit murine model of ARDS. As compared to $\mathrm{WT}_{(\mathrm{LPS}+\mathrm{MV})}$ mice, IL-6KO $\mathrm{K}_{(\mathrm{LPS}+\mathrm{MV})}$ mice showed a higher BAL cell count, a faster worsening of lung elastic properties during low tidal volume ventilation, and an acute pulmonary hypertension, the latter at least partially attributable to $\mathrm{NO}$-dependent vaso-active mechanisms. IL-6KO + rHuIL-6 ${ }_{(\mathrm{LPS}+\mathrm{MV})}$ mice experienced less severe lung injury, as shown by lower alveolitis and global lung injury scores, and a lower total pulmonary resistance as compared to IL-6KO $\mathrm{KO}_{(\mathrm{LPS}+\mathrm{MV})}$ mice.

The role of IL-6 in ARDS has been actively investigated over the past decades in various rodent models, including hyperoxia [14, 26], inhalation or aspiration of bacterial particles [15, 27], IgG aspiration [28], acid aspiration [29, 30], bacterial pneumonia [16], LPS intratracheal instillation [31] or aerosol inhalation [15] and high tidal volume-associated lung injury $[30,32]$. The role of IL-6 was evaluated using IL-6 overexpression $[14,26]$, recombinant IL-6 administration $[15,16,28,32]$, IL-6-blocking antibodies [28, 32] and IL-6 deficiency [15, 16, 29-32]. However, none of these studies included a model combining septic-like lung injury and protective mechanical ventilation. In the present work, we used a model clinically relevant to ARDS, the double-hit lung injury model [22], which combines LPS aspiration and low tidal volume ventilation. Lung infection is the most frequent cause of ARDS in humans [1]; low tidal volume ventilation has been shown to be protective during ARDS [33] and is commonly used in clinical practice [34].

Although no formal recommendations are available for ventilatory parameters in mice, we selected a tidal volume of $8 \mathrm{~mL} / \mathrm{kg}$, a value that was previously used by several research groups in murine protective mechanical ventilation [35-37]. The duration of low tidal volume mechanical ventilation was adequate as a hit in mice based on previously published work [8]. Our results support the merits of combining LPS and low tidal volume mechanical ventilation to elicit lung inflammation, injury, and an increase in alveolar-capillary permeability in mice. The double hit lung injury model is also characterized by acute pulmonary hypertension [22] and can be 


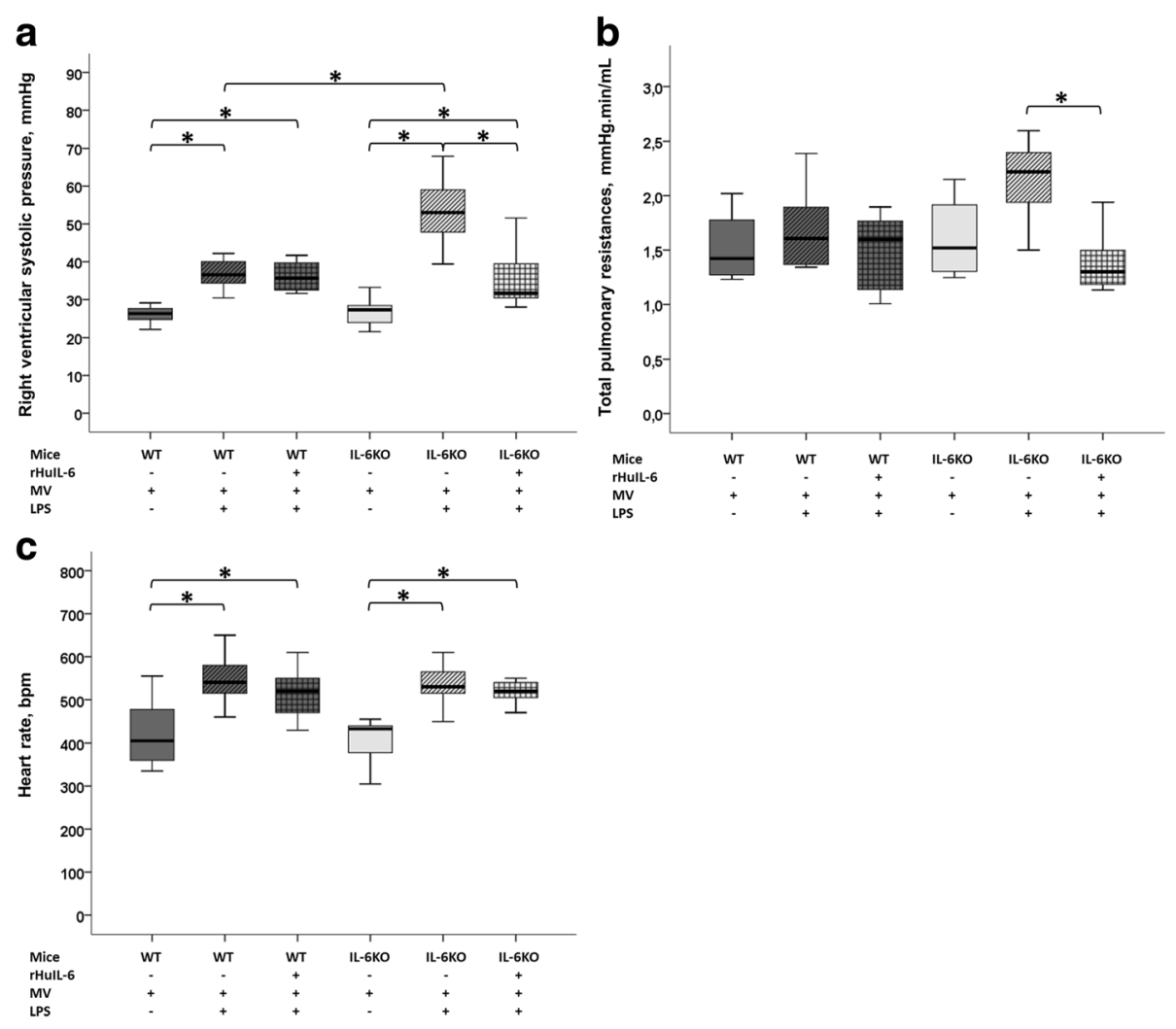

Fig. 6 Hemodynamic data obtained at the end of a 5-h low tidal volume mechanical ventilation (MV) following either a lipopolysaccharide (LPS) or vehicle (saline) aspiration in wild type (WT) and interleukin-6 knock-out (IL-6KO) mice receiving either recombinant human interleukin-6 (rHulL-6) or vehicle (saline). a Right ventricular systolic pressure $(\mathrm{mmHg})$. b Total pulmonary resistances ( $\mathrm{mmHg} . \mathrm{min} / \mathrm{mL})$. c Heart rate $(\mathrm{bpm})$. Right ventricular systolic pressure was measured during a short end-expiratory pause using an ultra-miniature catheter inserted into the right jugular vein and advanced into the right ventricle. Cardiac output was measured by the transpulmonary thermodilution technique. Total pulmonary resistances were calculated as the ratio of right ventricular systolic pressure to cardiac output (measured by the transpulmonary thermodilution technique). The symbol * denotes Benjamini-Hochberg corrected $p$ value $<0.05$ of Mann-Whitney pairwise comparisons (following Kruskal Wallis test). Data are presented as box and whiskers plots. $N=6$ to 8 animals per group

used to assess the consequences of IL-6 deficiency on the pulmonary vascular abnormalities typically seen in ARDS. To this end, we elected to use the model in IL-6 deficient mice and their control wild-type littermates. Surprisingly, we found the IL- 6 deficiency to be associated with a lower baseline quasi-static compliance in healthy and LPS-exposed animals. To the best of our knowledge, this phenotype of altered elastic lung properties had not been previously reported. Only one study by Tanaka et al. mentions a trend towards a lower lung compliance in IL-6 deficient mice as compared to wildtype controls [38].

Except for three studies [29-31], most investigations have shown that IL-6 exerts lung protective effects in ARDS [14-16, 26-28, 32]. In our study, there was a progressive worsening of elastic lung properties in wild-type and IL6-KO mice during low tidal volume ventilation, probably because of atelectasis [22, 39]. A new finding from our work is a faster worsening of lung elastic properties in IL-6-KO $\mathrm{KO}_{(\mathrm{LPS}+\mathrm{MV})}$ mice as compared to $\mathrm{WT}_{(\mathrm{LPS}+\mathrm{MV})}$.
Furthermore, IL-6KO mice experienced more severe pulmonary inflammation and injury in response to LPS aspiration and mechanical ventilation as compared to wild-type animals. The worst scores of edema, congestion, leukocyte infiltration and alveolitis, and the worst global lung injury score were actually seen in $\mathrm{IL}-6 \mathrm{KO}_{(\mathrm{LPS}+\mathrm{MV})}$ mice. In agreement with previous reports [32], treatment with exogenous IL-6 reduced histological lung damage in IL-6KO animals and lessened lung leukocyte infiltration in wild-type mice following challenge with LPS and mechanical ventilation. Furthermore, IL-6KO + HulL-6 $_{(\mathrm{LPS}+\mathrm{MV})}$ mice showed a trend toward a lower total protein concentration in BAL fluid and lung edema score when compared to IL- $6 \mathrm{KO}_{(\mathrm{LPS}+\mathrm{MV})}$ mice. This observation is consistent with previous reports showing that IL-6 decreases alveolar permeability and lung edema during lung injury $[28,32]$. In contrast, exogenous IL- 6 did not reverse the heightened BAL inflammation observed in IL-6KO mice challenged with 


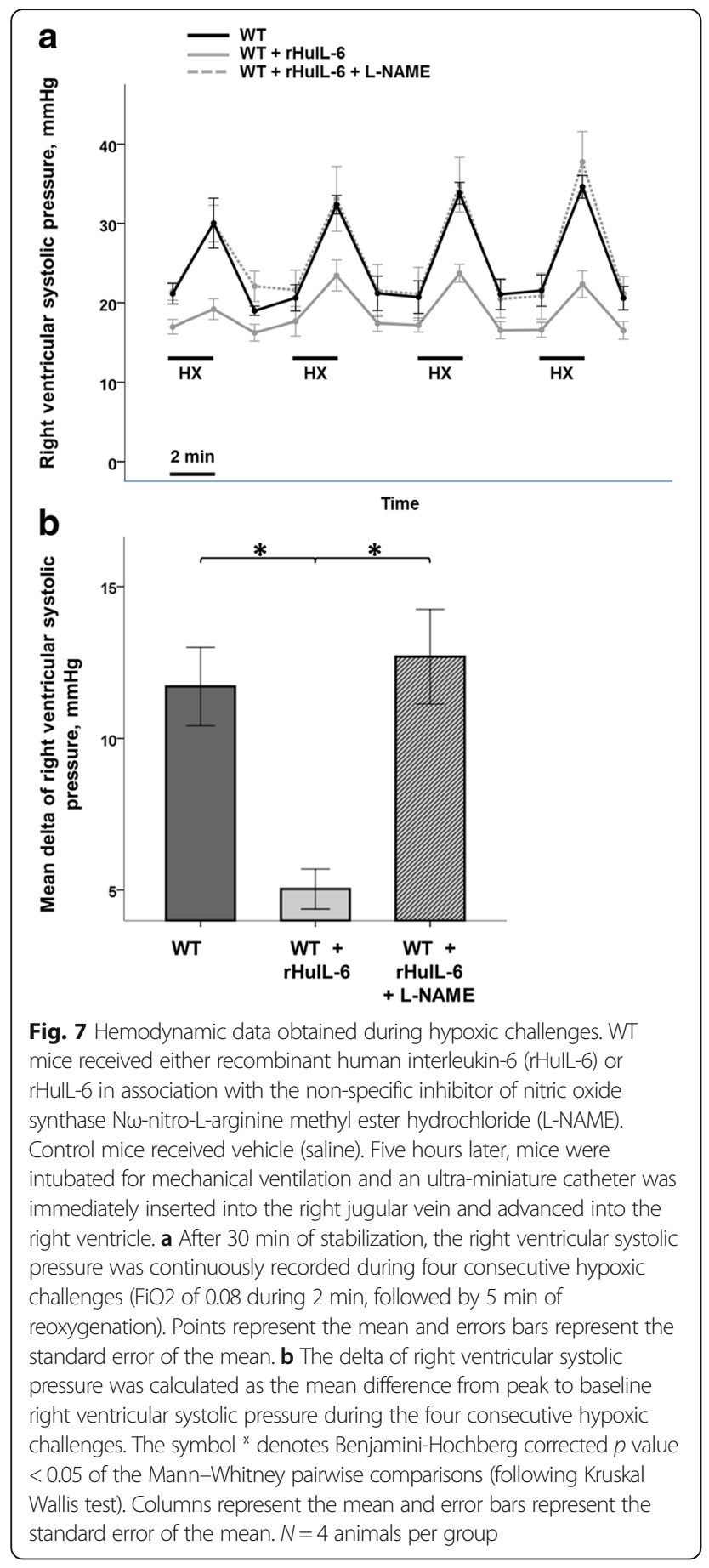

LPS and mechanical ventilation. Taken together, these data suggest differential effects of IL-6 in lung tissue and alveolar spaces [32].

Protective effects of IL-6 have been mostly reported in septic and septic-like induced ARDS. In addition to promoting inflammation, lung damage and edema, IL-6 deficiency alters bacterial clearance in experimental pneumonia [16, 40] and is associated with increased mortality following LPS aspiration [15]. Furthermore,
IL-6 exerts protective effects in extra-pulmonary sepsis models partly through its ability to inhibit apoptosis [20] and promote regeneration of hepatocytes [41]. Intratracheal treatment with recombinant IL-6 has been shown to exert anti-inflammatory effects in mice exposed to intratracheal LPS, with reduced BAL fluid cytokines and lung inflammation [42]. However, results in this research area have not been consistent. Two previous studies in non-septic models of ARDS showed IL-6 had deleterious properties $[29,30]$. Another investigation in a double-hit model reported conflicting results. Wild-type mice and IL-6KO mice were subjected to low-dose intratracheal LPS instillation $(0,2 \mathrm{mg} / \mathrm{kg})$ and 4-h high tidal volume $(20 \mathrm{~mL} / \mathrm{kg})$ mechanical ventilation alone and in combination. As compared to wild-type mice, IL-6KO mice in the combined group showed a significant decrease in bronchoalveolar cellular inflammation and lower histologic scores of lung injury [31]. However, the authors also reported a paradoxical increase in BAL fluid total protein in IL-6KO mice exposed to LPS alone as compared to their WT controls, a finding consistent with our own data. These conflicting observations suggest animal models are important factors to take into consideration when investigating IL-6 effects in ARDS.

ARDS may cause acute pulmonary hypertension [43], a condition associated with poor prognosis in patients $[17,44-46]$ and potentially worsened by mechanical ventilation, particularly when high PEEP [47] or highfrequency oscillatory ventilation [48] is used. The mechanism of this pulmonary vascular dysfunction is multifactorial, including partially dysregulated vasoreactivity [49]. In IL-6KO $\mathrm{K}_{(\mathrm{LPS}+\mathrm{MV})}$ animals, we observed an increase in total pulmonary resistance, as compared to $\mathrm{WT}_{(\mathrm{LPS}+\mathrm{MV})}$ mice and IL-6KO $+\mathrm{rHuIL}_{(\mathrm{LPS}+\mathrm{MV})}$ mice. We hypothesized that the acute pulmonary hypertension observed in our study could be related to a dysregulation of NO-dependent vasoactive mechanisms. Several studies have shown that IL-6 exerts acute systemic hemodynamics effects through this pathway. The acute administration of IL-6 produced a transient dosedependent systemic hypotension in rats [50]. In vitro, acute exposure of hamster papillary muscles [51] or cardiomyocytes [52] to IL-6 reduced contractility. This acute negative inotropic effect may result from an activation of endothelial NO synthase (eNOS) and inducible NO synthase (iNOS) [53], with a downstream decrease in intracellular $\mathrm{Ca}^{++}$influx [54]. Other studies have suggested that IL-6, in association with IL-1 $\beta$, is implicated in the NOS-dependent systemic vasodilatation seen during sepsis [55]. In the present study, rHuIL-6 treatment in healthy wild-type, hypoxia-challenged mice reduced hypoxic pulmonary vasoconstriction. This result is in agreement with in another paper by our team, which described a trend toward a higher hemodynamic response to acute 
hypoxia (5 min) in IL-6KO mice as compared to WT mice; conversely, IL-6-KO mice exhibited a lower right ventricular systolic pressure in response to chronic hypoxia (2 weeks) as compared to WT mice [56].

Because both eNOS and iNOS contribute to pulmonary vascular tone and modulate hypoxic pulmonary vasoconstriction [57], we tested the effects of the nonselective NOS inhibitor L-NAME. Its co-administration with rHuIL-6 totally restored hypoxic pulmonary vasoconstriction. This finding suggests a role for NOS isoforms in mediating the IL-6-induced inhibition of hypoxic pulmonary vasoconstriction. Therefore, the acute pulmonary hypertension observed during lung injury in LPS-exposed mice lacking endogenous IL-6 may be attributed in part to vasoactive mechanisms involving a dysregulation of NOS isoforms. This hypothesis will have to be fully investigated in future studies. Of note, the effects of IL-6-related inhibition of hypoxic pulmonary vasoconstriction may be considered either beneficial on right-sided hemodynamics or deleterious on gas exchange. The clinical relevance of these changes must be kept in mind when debating the potential therapeutic applications of rHuIL-6 in patients with ARDS.

The hemodynamic changes observed in IL- $6 \mathrm{KO}_{(\mathrm{LPS}}$ $+\mathrm{MV})$ mice may cause further lung injury and/or inflammation via a direct mechanism. Several studies support this conclusion. Following pulmonary artery banding to induce pre-capillary pulmonary hypertension and subsequent right heart failure in mice, Vistnes et al. quantified circulating cytokines levels and observed an increase in IL-1 $\alpha$, IL-6, G-CSF and CXCL9 as compared to sham operated mice [58]. In another study, Costa-Souza et al. induced pre-capillary pulmonary hypertension and quantified pulmonary inflammation in a rat model of microsphere-induced pulmonary embolism. The authors observed an increase in bronchoalveolar neutrophils as compared to control rats [59]. Taken together, the results from these two non-septic rodent models of acute pre-capillary pulmonary hypertension suggest the elevated right ventricular systolic pressure (or pulmonary arterial pressure) might contribute directly to pulmonary and systemic inflammation. Previous work from our research group suggests additional factors may be involved. In a LPS-challenged mice model, 5-h mechanical ventilation using low tidal volume inflation alone or in combination with intermittent deep inflations produced a significant rise in right ventricular systolic pressures and pulmonary vascular resistance. However, we did not observe any increase in lung and systemic inflammation [22].

Our study has several limitations. First, we did not measure systemic blood pressure, and assumed no differences were present between groups. This assumption is reasonable considering previously available results showing that baseline systemic blood pressure is similar in WT and IL-6KO mice [60]. Second, we also assumed that left-sided myocardial function and pressures did not differ between groups. This assumption is supported by previous findings that intravenous exogenous IL- 6 exerts only very transient left-sided hemodynamic effects in rodents [50].

\section{Conclusions}

In a septic-like double-hit murine model of ARDS (LPS aspiration followed by 5 -h low tidal volume mechanical ventilation), we found that IL-6 deficiency caused a more severe bronchoalveolar cellular inflammation and a faster deterioration of lung elastic properties during low tidal volume ventilation. This higher severity was partially reversed by exogenous IL-6, which mitigated the histological injury observed in IL-6 deficient mice challenged with LPS and mechanical ventilation. Furthermore, IL-6 deficiency was associated with marked acute pulmonary hypertension, which was prevented by exogenous IL- 6 administration. IL- 6 acted as limiting the hypoxic pulmonary vasoconstriction, most probably by regulating the NO pathway. Future studies are needed to reconcile the discrepancy between the commonly recognized merits of using IL- 6 concentrations as a detrimental prognostic factor in sepsis in a clinical setting and its protective role in experimental sepsis and ARDS.

\section{Abbreviations \\ ALI: Acute lung injury; ARDS: Acute respiratory distress syndrome; BAL: Broncho-alveolar lavage; eNOS: Endothelial nitric oxyde synthase; IL- 6: Interleukin-6; IL-6KO: Interleukin-6 knock-out; iNOS: Inducible nitric oxyde synthase; L-NAME: N $\omega$-nitro-L-arginine methyl ester hydrochloride; rHulL- 6: Recombinant human interleukin-6; RVSP: Right ventricular systolic pressure; WT: Wild-type}

\section{Acknowledgments}

None.

\section{Funding}

GV was a recipient from the Fondation de Recherche Médicale (FRM) and from the Fond de Recherche en Santé Respiratoire (FRSR). The Academy of Paris (Legs Poix) provided a supplementary grant to support the study.

\section{Availability of data and materials}

All data generated and analyzed during the study are included in the published article and can be shared upon request.

\section{Authors' contributions}

GV had full access to all the data in the study and takes responsibility for the integrity of the data and the accuracy of its analysis. GV participated in the design of the study, conducted the animal studies, participated in the data acquisition, analysis and interpretation, and the statistical analysis, and drafted the manuscript. KR participated in the animal studies, the data acquisition, analysis and interpretation, and helped to draft the manuscript VA participated in the biological studies, the data acquisition, analysis and interpretation, and helped to draft the manuscript. JTVN conducted the histological analysis and helped to revise the manuscript. ShA participated in the biological studies, the data acquisition, analysis and interpretation. SeA participated in the design of the study, the data analysis and interpretation, and helped to revise the manuscript. AMD and BM designed the study, participated in the data analysis and interpretation, and the statistical analysis, and revised the manuscript. 


\section{Competing interests}

The authors have reported that no potential conflicts of interest exist with any companies/organizations whose products or services may be discussed in this article.

\section{Consent for publication}

Not applicable

\section{Ethics approval and consent to participate}

All animal care and procedures were approved by the Institutional Animal Care Committee (Comité d'Ethique en Matière d'Expérimentation Animale, ComEth ANSES/ENVAVUPEC), in accordance with the official guidelines of the French Ministry of Agriculture for the experimental use of animals.

\section{Publisher's Note}

Springer Nature remains neutral with regard to jurisdictional claims in published maps and institutional affiliations.

\section{Author details}

'INSERM, Unité U955 (Institut Mondor de Recherche Biomédicale), Créteil, France. ${ }^{2}$ Faculté de Médecine, Groupe de recherche clinique CARMAS, Université Paris Est, Créteil, France. ${ }^{3}$ Groupe Henri Mondor-Albert Chenevier, Hôpital Henri Mondor, Service de Réanimation Médicale, AP-HP, Créteil, France. ${ }^{4}$ Groupe Henri Mondor-Albert Chenevier, Hôpital Henri Mondor, Service d'Anatomie et Cytologie Pathologiques, AP-HP, Créteil, France. ${ }^{5}$ Groupe Henri Mondor-Albert Chenevier, Hôpital Henri Mondor, Service des Explorations Fonctionnelles, AP-HP, Créteil, France.

Received: 26 September 2016 Accepted: 13 April 2017 Published online: 19 April 2017

\section{References}

1. Rubenfeld GD, Caldwell E, Peabody E, Weaver J, Martin DP, Neff M, Stern EJ, Hudson LD. Incidence and outcomes of acute lung injury. N Engl J Med. 2005;353(16):1685-93.

2. Ware LB, Matthay MA. The acute respiratory distress syndrome. N Engl J Med. 2000;342(18):1334-49.

3. Gadient RA, Patterson PH. Leukemia inhibitory factor, Interleukin 6, and other cytokines using the GP130 transducing receptor: roles in inflammation and injury. Stem Cells. 1999;17(3):127-37.

4. Fattori E, Cappelletti M, Costa P, Sellitto C, Cantoni L, Carelli M, Faggioni R, Fantuzzi G, Ghezzi P, Poli V. Defective inflammatory response in interleukin 6-deficient mice. J Exp Med. 1994;180(4):1243-50.

5. Tremblay L, Valenza F, Ribeiro SP, Li J, Slutsky AS. Injurious ventilatory strategies increase cytokines and c-fos m-RNA expression in an isolated rat lung model. J Clin Invest. 1997;99(5):944-52.

6. Veldhuizen RA, Slutsky AS, Joseph M, McCaig L. Effects of mechanical ventilation of isolated mouse lungs on surfactant and inflammatory cytokines. Eur Respir J. 2001;17(3):488-94.

7. Stüber F, Wrigge $H$, Schroeder S, Wetegrove S, Zinserling J, Hoeft A, Putensen C. Kinetic and reversibility of mechanical ventilation-associated pulmonary and systemic inflammatory response in patients with acute lung injury. Intensive Care Med. 2002;28(7):834-41.

8. Vaporidi K, Voloudakis G, Priniannakis G, Kondili E, Koutsopoulos A, Tsatsanis C, Georgopoulos D. Effects of respiratory rate on ventilator-induced lung injury at a constant $\mathrm{PaCO} 2$ in a mouse model of normal lung. Crit Care Med. 2008;36(4):1277-83.

9. Ranieri VM, Suter PM, Tortorella C, De Tullio R, Dayer JM, Brienza A, Bruno S, Slutsky AS. Effect of mechanical ventilation on inflammatory mediators in patients with acute respiratory distress syndrome: a randomized controlled trial. Jama J Am Med Assoc. 1999;282(1):54-61.

10. Parsons PE, Eisner MD, Thompson BT, Matthay MA, Ancukiewicz M, Bernard GR, Wheeler AP. Lower tidal volume ventilation and plasma cytokine markers of inflammation in patients with acute lung injury. Crit Care Med. 2005;33(1):1-6. discussion 230-232.

11. Frank JA, Parsons PE, Matthay MA. Pathogenetic significance of biological markers of ventilator-associated lung injury in experimental and clinical studies. Chest. 2006;130(6):1906-14.

12. Remick DG, Bolgos G, Copeland S, Siddiqui J. Role of interleukin-6 in mortality from and physiologic response to sepsis. Infect Immun. 2005;73(5):2751-7.
13. O'Malley K, Moldawer L. Interleukin-6: Still crazy after all these years. Crit Care Med. 2006:34(10):2690-1.

14. Ward NS, Waxman AB, Homer RJ, Mantell LL, Einarsson O, Du Y, Elias JA. Interleukin-6-induced protection in hyperoxic acute lung injury. Am J Respir Cell Mol Biol. 2000;22(5):535-42.

15. Xing Z, Gauldie J, Cox G, Baumann H, Jordana M, Lei XF, Achong MK. IL-6 is an antiinflammatory cytokine required for controlling local or systemic acute inflammatory responses. J Clin Invest. 1998;101(2):311-20.

16. Jones MR, Quinton LJ, Simms BT, Lupa MM, Kogan MS, Mizgerd JP. Roles of interleukin- 6 in activation of STAT proteins and recruitment of neutrophils during Escherichia coli pneumonia. J Infect Dis. 2006;193(3):360-9.

17. Bull TM, Clark B, McFann K, Moss M. National Institutes of Health/National Heart, Lung, and Blood Institute ARDS Network. Pulmonary vascular dysfunction is associated with poor outcomes in patients with acute lung injury. Am J Respir Crit Care Med. 2010;182(9):1123-8.

18. Kopf M, Baumann H, Freer G, Freudenberg M, Lamers M, Kishimoto T, Zinkernagel R, Bluethmann H, Köhler G. Impaired immune and acute-phase responses in interleukin-6-deficient mice. Nature. 1994;368(6469):339-42.

19. Yardeni T, Eckhaus M, Morris HD, Huizing M, Hoogstraten-Miller S. Retroorbital injections in mice. Lab Anim. 2011;40(5):155-60.

20. Arikan AA, Yu B, Mastrangelo MA, Tweardy DJ. Interleukin-6 treatment reverses apoptosis and blunts susceptibility to intraperitoneal bacterial challenge following hemorrhagic shock. Crit Care Med. 2006;34(3):771-7.

21. Matsushita K, Iwanaga S, Oda T, Kimura K, Shimada M, Sano M, Umezawa A, Hata J, Ogawa S. Interleukin-6/soluble interleukin-6 receptor complex reduces infarct size via inhibiting myocardial apoptosis. Lab Invest. 2005;85(10):1210-23.

22. Mekontso Dessap A, Voiriot G, Zhou T, Marcos E, Dudek SM, Jacobson JR, Machado R, Adnot S, Brochard L, Maitre B, Garcia JG. Conflicting physiological and genomic cardiopulmonary effects of recruitment maneuvers in murine acute lung injury. Am J Respir Cell Mol Biol. 2012;46(4):541-50.

23. Champion HC, Villnave DJ, Tower A, Kadowitz PJ, Hyman AL. A novel right-heart catheterization technique for in vivo measurement of vascular responses in lungs of intact mice. Am J Physiol Heart Circ Physiol. 2000;278(1):H8-H15.

24. Belperio JA, Keane MP, Burdick MD, Londhe V, Xue YY, Li K, Phillips RJ, Strieter RM. Critical role for CXCR2 and CXCR2 ligands during the pathogenesis of ventilator-induced lung injury. J Clin Invest. 2002;110(11):1703-16.

25. Nishina K, Mikawa K, Takao Y, Shiga M, Maekawa N, Obara H. Intravenous lidocaine attenuates acute lung injury induced by hydrochloric acid aspiration in rabbits. Anesthesiology. 1998;88(5):1300-9.

26. Kolliputi N, Waxman AB. IL-6 cytoprotection in hyperoxic acute lung injury occurs via suppressor of cytokine signaling-1-induced apoptosis signal-regulating kinase-1 degradation. Am J Respir Cell Mol Biol. 2009;40(3):314-24.

27. Leemans JC, Vervoordeldonk MJBM, Florquin S, van Kessel KP, van der Poll T. Differential role of interleukin- 6 in lung inflammation induced by lipoteichoic acid and peptidoglycan from Staphylococcus aureus. Am J Respir Crit Care Med. 2002;165(10):1445-50.

28. Shanley TP, Foreback JL, Remick DG, Ulich TR, Kunkel SL, Ward PA. Regulatory effects of interleukin-6 in immunoglobulin G immune-complexinduced lung injury. Am J Pathol. 1997;151(1):193-203.

29. Imai Y, Kuba K, Neely GG, Yaghubian-Malhami R, Perkmann T, van Loo G, Ermolaeva M, Veldhuizen R, Leung YH, Wang H, Liu H, Sun Y, Pasparakis M, Kopf M, Mech C, Bavari S, Peiris JS, Slutsky AS, Akira S, Hultqvist M, Holmdahl R, Nicholls J, Jiang C, Binder CJ, Penninger JM. Identification of oxidative stress and Toll-like receptor 4 signaling as a key pathway of acute lung injury. Cell. 2008;133(2):235-49.

30. Gurkan OU, He C, Zielinski R, Rabb H, King LS, Dodd-o JM, D'Alessio FR, Aggarwal N, Pearse D, Becker PM. Interleukin-6 mediates pulmonary vascular permeability in a two-hit model of ventilator-associated lung injury. Exp Lung Res. 2011;37(10):575-84.

31. Goldman JL, Sammani S, Kempf C, Saadat L, Letsiou E, Wang T, MorenoVinasco L, Rizzo AN, Fortman JD, Garcia JG. Pleiotropic effects of interleukin6 in a "two-hit" murine model of acute respiratory distress syndrome. Pulm Circ. 2014;4(2):280-8.

32. Wolters PJ, Wray C, Sutherland RE, Kim SS, Koff J, Mao Y, Frank JA. Neutrophilderived IL-6 limits alveolar barrier disruption in experimental ventilator-induced lung injury. J Immunol. 2009;182(12):8056-62.

33. The Acute Respiratory Distress Syndrome Network. Ventilation with lower tidal volumes as compared with traditional tidal volumes for 
acute lung injury and the acute respiratory distress syndrome. N Engl J Med. 2000;342(18):1301-8.

34. Esteban A, Ferguson ND, Meade MO, Frutos-Vivar F, Apezteguia C, Brochard L, Raymondos K, Nin N, Hurtado J, Tomicic V, González M, Elizalde J, Nightingale P, Abroug F, Pelosi P, Arabi Y, Moreno R, Jibaja M, D’Empaire G, Sandi F, Matamis D, Montañez AM, Anzueto A. Evolution of mechanical ventilation in response to clinical research. Am J Respir Crit Care Med. 2008;177(2):170-7.

35. Halbertsma FJ, Vaneker M, Pickkers P, Snijdelaar DG, van Egmond J, Scheffer GJ, van der Hoeven HG. Hypercapnic acidosis attenuates the pulmonary innate immune response in ventilated healthy mice. Crit Care Med. 2008;36(8):2403-6.

36. Maniatis NA, Kardara M, Hecimovich D, Letsiou E, Castellon M, Roussos C, Shinin V, Votta-Vellis EG, Schwartz DE, Minshall RD. Role of caveolin1expression in the pathogenesis of pulmonary edema in ventilator-induced lung injury. Pulm Circ. 2012;2(4):452-60.

37. Manitsopoulos N, Orfanos SE, Kotanidou A, Nikitopoulou I, Siempos I, Magkou C, Dimopoulou I, Zakynthinos SG, Armaganidis A, Maniatis NA. Inhibition of HMGCoA reductase by simvastatin protects mice from injurious mechanical ventilation. Respir Res. 2015;16:24.

38. Tasaka S, Inoue K-I, Miyamoto K, Nakano Y, Kamata H, Shinoda H, Hasegawa N, Miyasho T, Satoh M, Takano H, Ishizaka A. Role of interleukin- 6 in elastase-induced lung inflammatory changes in mice. Exp Lung Res. 2010;36(6):362-72.

39. Allen GB, Suratt BT, Rinaldi L, Petty JM, Bates JHT. Choosing the frequency of deep inflation in mice: balancing recruitment against ventilator-induced lung injury. Am J Physiol Lung Cell Mol Physiol. 2006;291(4):L710-717.

40. Dalrymple SA, Slattery R, Aud DM, Krishna M, Lucian LA, Murray R. Interleukin-6 is required for a protective immune response to systemic Escherichia coli infection. Infect Immun. 1996;64(8):3231-5.

41. Deutschman CS, Cereda M, Ochroch EA, Raj NR. Sepsis-induced cholestasis, steatosis, hepatocellular injury, and impaired hepatocellular regeneration are enhanced in interleukin-6 -/- mice. Crit Care Med. 2006;34(10):2613-20.

42. Bhargava R, Janssen W, Altmann C, Andrés-Hernando A, Okamura K, Vandivier RW, Ahuja N, Faubel S. Intratracheal IL-6 protects against lung inflammation in direct, but not indirect, causes of acute lung injury in mice. PLoS One. 2013;8(5):e61405.

43. Zapol WM, Snider MT. Pulmonary hypertension in severe acute respiratory failure. N Engl J Med. 1977;296(9):476-80.

44. Villar J, Blazquez MA, Lubillo S, Quintana J, Manzano JL. Pulmonary hypertension in acute respiratory failure. Crit Care Med. 1989;17(6):523-6.

45. Monchi M, Bellenfant F, Cariou A, Joly LM, Thebert D, Laurent I, Dhainaut JF, Brunet F. Early predictive factors of survival in the acute respiratory distress syndrome. A multivariate analysis. Am J Respir Crit Care Med. 1998;158(4):1076-81.

46. Boissier F, Katsahian S, Razazi K, Thille AW, Roche-Campo F, Leon R, Vivier E, Brochard L, Vieillard-Baron A, Brun-Buisson C, Mekontso DA. Prevalence and prognosis of cor pulmonale during protective ventilation for acute respiratory distress syndrome. Intensive Care Med. 2013;39(10):1725-33.

47. Vieillard-Baron A, Schmitt JM, Augarde R, Fellahi JL, Prin S, Page B, Beauchet A, Jardin F. Acute cor pulmonale in acute respiratory distress syndrome submitted to protective ventilation: incidence, clinical implications, and prognosis. Crit Care Med. 2001;29(8):1551-5.

48. Guervilly C, Forel JM, Hraiech S, Demory D, Allardet-Servent J, Adda M, Barreau-Baumstark K, Castanier M, Papazian L, Roch A. Right ventricular function during high-frequency oscillatory ventilation in adults with acute respiratory distress syndrome. Crit Care Med. 2012;40(5):1539-45.

49. Moloney ED, Evans TW. Pathophysiology and pharmacological treatment of pulmonary hypertension in acute respiratory distress syndrome. Eur Respir J. 2003;21(4):720-7.

50. Comini L, Pasini E, Bachetti T, Dreano M, Garotta G, Ferrari R. Acute haemodynamic effects of IL-6 treatment in vivo: involvement of vagus nerve in NO-mediated negative inotropism. Cytokine. 2005;30(5):236-42.

51. Finkel MS, Oddis CV, Jacob TD, Watkins SC, Hattler BG, Simmons RL. Negative inotropic effects of cytokines on the heart mediated by nitric oxide. Science. 1992;257(5068):387-9.

52. Kinugawa K, Takahashi T, Kohmoto O, Yao A, Aoyagi T, Momomura S, Hirata Y, Serizawa T. Nitric oxide-mediated effects of interleukin-6 on $[\mathrm{Ca} 2+] \mathrm{i}$ and cell contraction in cultured chick ventricular myocytes. Circ Res. 1994;75(2):285-95.
53. Yu X, Kennedy RH, Liu SJ. JAK2/STAT3, not ERK1/2, mediates interleukin-6induced activation of inducible nitric-oxide synthase and decrease in contractility of adult ventricular myocytes. J Biol Chem. 2003;278(18):16304-9.

54. Yu X-W, Chen Q, Kennedy RH, Liu SJ. Inhibition of sarcoplasmic reticular function by chronic interleukin-6 exposure via iNOS in adult ventricular myocytes. J Physiol. 2005;566(Pt 2):327-40.

55. Bhagat K, Hingorani AD, Palacios M, Charles IG, Vallance P. Cytokine-induced venodilatation in humans in vivo: eNOS masquerading as iNOS. CardiovasC Res. 1999;41(3):754-64

56. Savale L, Tu L, Rideau D, Izziki M, Maitre B, Adnot S, Eddahibi S. Impact of interleukin-6 on hypoxia-induced pulmonary hypertension and lung inflammation in mice. Respir Res. 2009;10:6.

57. Fagan KA, Tyler RC, Sato K, Fouty BW, Morris Jr KG, Huang PL, McMurtry IF, Rodman DM. Relative contributions of endothelial, inducible, and neuronal NOS to tone in the murine pulmonary circulation. Am J Physiol. 1999;277(3 Pt 1):L472-478.

58. Vistnes M, Waehre A, Nygård S, Sjaastad I, Andersson KB, Husberg C, Christensen G. Circulating cytokine levels in mice with heart failure are etiology dependent. J Appl Physiol. 2010;108(5):1357-64.

59. Souza-Costa DC, Figueiredo-Lopes L, Alves-Filho JC, Semprini MC, Gerlach RF, Cunha FQ, Tanus-Santos JE. Protective effects of atorvastatin in rat models of acute pulmonary embolism: involvement of matrix metalloproteinase-9. Crit Care Med. 2007;35(1):239-45.

60. Schrader LI, Kinzenbaw DA, Johnson AW, Faraci FM, Didion SP. IL-6 deficiency protects against angiotensin II induced endothelial dysfunction and hypertrophy. Arterioscler Thromb Vasc Biol. 2007;27(12):2576-81.

\section{Submit your next manuscript to BioMed Central and we will help you at every step:}

- We accept pre-submission inquiries

- Our selector tool helps you to find the most relevant journal

- We provide round the clock customer support

- Convenient online submission

- Thorough peer review

- Inclusion in PubMed and all major indexing services

- Maximum visibility for your research

Submit your manuscript at www.biomedcentral.com/submit
Biomed Central 